\title{
Ring1b bookmarks genes in pancreatic embryonic progenitors for repression in adult $\beta$ cells
}

\author{
Joris van Arensbergen, ${ }^{1,2,6}$ Javier García-Hurtado, ${ }^{1,2}$ Miguel Angel Maestro, ${ }^{1,2}$ Miguel Correa-Tapia, ${ }^{1,2}$ \\ Guy A. Rutter, ${ }^{3}$ Miguel Vidal, ${ }^{4}$ and Jorge Ferrer ${ }^{1,2,3,5}$ \\ ${ }^{1}$ Genomic Programming of Beta Cells Laboratory, Institut d'Investigacions Biomèdiques August Pi i Sunyer (IDIBAPS), 08036 \\ Barcelona, Spain; ${ }^{2}$ Centros de Investigación Biomédica en Red (CIBER) de Diabetes y Enfermedades Metabólicas, 08036 \\ Barcelona, Spain; ${ }^{3}$ Department of Medicine, Imperial College, London W12 0NN, United Kingdom; ${ }^{4}$ Cellular and Molecular \\ Biology, Centro de Investigaciones Biológicas, Consejo Superior de Investigaciones Científicas (CSIC), 28040 Madrid, Spain; \\ ${ }^{5}$ Department of Endocrinology, Hospital Clínic de Barcelona, 08036 Barcelona, Spain
}

Polycomb-mediated gene repression is essential for embryonic development, yet its precise role in lineage-specific programming is poorly understood. Here we inactivated Ring1b, encoding a polycomb-repressive complex 1 subunit, in pancreatic multipotent progenitors $\left(\operatorname{Ring} 1 b^{\text {progKO}}\right)$. This caused transcriptional derepression of a subset of direct Ring1b target genes in differentiated pancreatic islet cells. Unexpectedly, Ring1 $b$ inactivation in differentiated islet $\beta$ cells $\left(\operatorname{Ring}_{1} b^{\beta \mathrm{KO}}\right)$ did not cause derepression, even after multiple rounds of cell division, suggesting a role for Ring1b in the establishment but not the maintenance of repression. Consistent with this notion, derepression in Ring $1 b^{\text {progKO }}$ islets occurred preferentially in genes that were targeted de novo by Ring1b during pancreas development. The results support a model in which Ring1b bookmarks its target genes during embryonic development, and these genes are maintained in a repressed state through Ring1b-independent mechanisms in terminally differentiated cells. This work provides novel insights into how epigenetic mechanisms contribute to shaping the transcriptional identity of differentiated lineages.

[Keywords: Ring1b; Polycomb; pancreatic $\beta$ cells; cellular programming; epigenetics]

Supplemental material is available for this article.

Received September 15, 2012; revised version accepted November 26, 2012.

Throughout embryonic development, an interplay between positive and negative regulatory mechanisms promotes dynamic changes in chromatin structure that set up lineage-specific transcriptional programs. Although current knowledge supports this general model, the exact manner in which chromatin regulatory complexes contribute to differentiation programs remains to be defined.

One of the key mechanisms to create repressive chromatin states is mediated by Polycomb group (PcG) proteins (Sparmann and van Lohuizen 2006; Schwartz and Pirrotta 2007; Schuettengruber and Cavalli 2009; Vidal 2009; Margueron and Reinberg 2011). PcG proteins form two major families of complexes, named Polycomb-repressive complex 1 (PRC1) and PRC2. PRC2 comprises Eed, Suz12, and two related subunits, Ezh1 and Ezh2, that catalyze the trimethylation of histone H3K27 (H3K27me3).

\footnotetext{
${ }^{6}$ Present address: Division of Gene Regulation, Netherlands Cancer Institute, Amsterdam 1066 CX, The Netherlands Corresponding author

E-mail j.ferrer@imperial.ac.uk

Article published online ahead of print. Article and publication date are online at http://www.genesdev.org/cgi/doi/10.1101/gad.206094.112.
}

PRC1 complexes include Bmil, Cbx proteins, Mel18, and the ring finger proteins Ringla and Ringlb (Vidal 2009). Among these, Ringlb has a primary role in catalyzing another post-translational histone modification, H2A K119 ubiquitination (de Napoles et al. 2004; Wang et al. 2004). Ringlb-mediated repression is linked to H2A ubiquitination, although Ring1b also promotes chromatin compaction independently of this histone-modifying activity (Eskeland et al. 2010). Thus, many of the molecular components and mechanisms underlying PcG-mediated repression have begun to be unraveled.

Multiple lines of evidence indicate that PcG proteins are pivotal for embryonic developmental programs. Notably, several Drosophila and mouse PcG mutants have shown embryonic lethality or homeotic transformations due to derepression of Hox genes (e.g., Lewis 1978; O'Carroll et al. 2001; Voncken et al. 2003). Furthermore, PcG proteins show a strong preference to bind inactive genes that encode for developmental regulators, and PcG-dependent modifications are dynamically placed and removed at key lineage regulatory genes throughout pancreatic and neural differentiation (Boyer et al. 2006; 
Bracken et al. 2006; Lee et al. 2006; Mohn et al. 2008; van Arensbergen et al. 2010). The precise role of PcG proteins in developmental programs, however, is still poorly understood. In part, this is because many germline PcG mutant models exhibit early lethality (Faust et al. 1998; O'Carroll et al. 2001; Voncken et al. 2003; Pirity et al. 2005). A good example is provided by Ring $1 b$ mutations, which (unlike Ring1a deficiency) causes defective gastrulation and embryonic lethality (del Mar Lorente et al. 2000; Voncken et al. 2003). For viable genetic mutations, including $\mathrm{Bmi1}^{-1-}$ or conditionally inactive Ezh2 mice, studies have so far largely uncovered severe self-renewal defects (e.g., Jacobs et al. 1999; Chen et al. 2009; Dhawan et al. 2009|. Recent studies, however, have begun to address how PcG proteins control cellular differentiation from tissue-specific progenitors. For example, during normal differentiation of epidermal progenitors, Ezh2 levels are down-regulated, leading to the activation of genes associated with epidermis differentiation (Ezhkova et al. 2009). Consequently, inactivation of Ezh2 in basal skin progenitors has led to premature epidermal differentiation. In the ventral foregut endoderm, Ezh2 has been shown to restrict the pancreatic fate choice (Xu et al. 2011). Other experiments suggest that Ezh2 and Ring $1 b$ restrict neurogenesis to early developmental stages by repressing the proneural genes Neurogenin1 and NeuroD1 during the later astrogenic stage (Hirabayashi et al. 2009; RomanTrufero et al. 2009). It is thus evident that PcG-dependent repression plays crucial developmental roles, although there is still a limited understanding of the detailed roles that PcG-mediated repression plays throughout different stages of lineage-specific programs.

After the specification and differentiation of cellular lineages, transcriptional states are maintained throughout multiple rounds of cell division. PcG-dependent repressive mechanisms have also been proposed to underlie long-term maintenance of cellular identity (Ringrose and Paro 2007). However, ablation of PcG genes in differentiated cells has led to proliferative defects without obvious loss of cellular identity, although genetic studies reported so far have not directly addressed effects on the transcriptional programs of differentiated lineages (e.g., Chen et al. 2009; Juan et al. 2011). Thus, further studies are required to address whether PcG proteins maintain the cellular identity of differentiated cells.

In this study, we created conditional mutations of the PRC1 subunit gene Ring $1 b$ to address the stage-specific functions of PcG-mediated repression during the embryonic differentiation of pancreatic $\beta$ cells. Our results show that during embryonic differentiation, Ring $1 \mathrm{~b}$ is required to establish the transcriptional repression of target genes in the differentiated $\beta$-cell lineage, despite the fact that the maintenance of this repression in terminally differentiated $\beta$ cells is independent of Ring $1 \mathrm{~b}$. We created cell lines from mice with stage-specific mutations to demonstrate that the transcriptional phenotypes are mitotically stable and integrated expression and occupancy studies to show that they reflect a direct function of Ringlb. The results therefore reveal separate mechanisms that either establish or maintain the repression of a discrete set of genes in a cellular lineage and provide novel insights into how PcG-mediated repression contributes to shaping the transcriptional identity of pancreatic $\beta$ cells.

\section{Results}

Stage-specific inactivation of Ring $1 \mathrm{~b}$ during $\beta$-cell differentiation

To study the stage-specific functions of PRC1 during pancreatic $\beta$-cell development, we crossed mice with a conditional Ring $1 b$ LoxP allele and either Pdx1-Cre or Ins-Cre transgenic lines (Fig. 1A; Herrera 2000; Gu et al. 2002; Cales et al. 2008). Ringlb is expressed in multipotent embryonic pancreatic progenitors, the mesenchyme, and the adult islet $\beta$ cells (Fig. 1B,E,G,I). The Pdx1-Cre transgene efficiently deleted Ring $1 b$ in embryonic pancreatic progenitors and adult $\beta$ cells (Ring $1 b^{\text {progKO}}$ ), while Ins-Cre caused efficient recombination in lineage-committed $\beta$ cells (Ring $\left.1 b^{\beta K O}\right)$ (Fig. 1C,D,F,H,J).

\section{Early but not late Ringlb inactivation leads to impaired islet endocrine function}

To assess the consequences of stage-specific ablation of Ring $1 b$ in pancreatic cells, we first studied glucose tolerance in 4-mo-old mice. Ring $1 b^{\text {progKO }}$ mice displayed increased blood glucose levels during a meal test (Fig. 2A) and after intraperitoneal injection of glucose (Fig. 2B). This impairment was due to decreased blood insulin levels (Fig. 2C). In sharp contrast, Ring $1 b^{\beta \mathrm{KO}}$ mice showed normal glucose tolerance and insulin secretion (Fig. 2E-G). Thus, early but not late Ring1b inactivation caused decreased insulin output and glucose intolerance.

We next assessed whether glucose intolerance in Ring $1 b^{\text {progKO }}$ mice resulted from an abnormal number of $\beta$ cells. Previous studies showed that deficiency of other PcG subunits induces transcripts from the $C d k n 2 a$ locus, leading to reduced $\beta$-cell growth (Chen et al. 2009; Dhawan et al. 2009). Ring $1 b^{\text {progKO }}$ and Ring $1 b^{\beta K O}$ islets showed moderately increased Cdkn2a transcripts (Supplemental Fig. 1), yet this was not sufficient to cause significant changes in $\beta$-cell mass (Fig. 2D, $\mathrm{H}$; Supplemental Fig. 2A). Thus, the inactivation of Ring $1 b$ during early pancreatic development results in a functional impairment of adult $\beta$ cells, whereas Ring $1 b$ inactivation in lineage-committed $\beta$ cells does not.

\section{Early but not late Ringlb inactivation causes derepression of a subset of Ring $1 b$ targets}

To investigate whether the impairment of islet endocrine function resulted from a transcriptional perturbation of Ring $1 \mathrm{~b}$ targets, we assessed transcriptional changes in Ring $1 b^{\text {progKO }}$ islets. Consistent with the fact that Ring $1 b$ is a component of a transcriptional repressive complex, we observed a marked derepression phenotype in Ring $1 b^{\text {progKO }}$ islets, with significantly more probes showing up-regulation $(n=398)$ than down-regulation $\left(n=179 ; P<2.2 \times 10^{-16}\right)$ (Fig 3A; Supplemental Table 1).

To assess whether this transcriptional response reflected a derepression of direct Ringlb targets, we used 
A
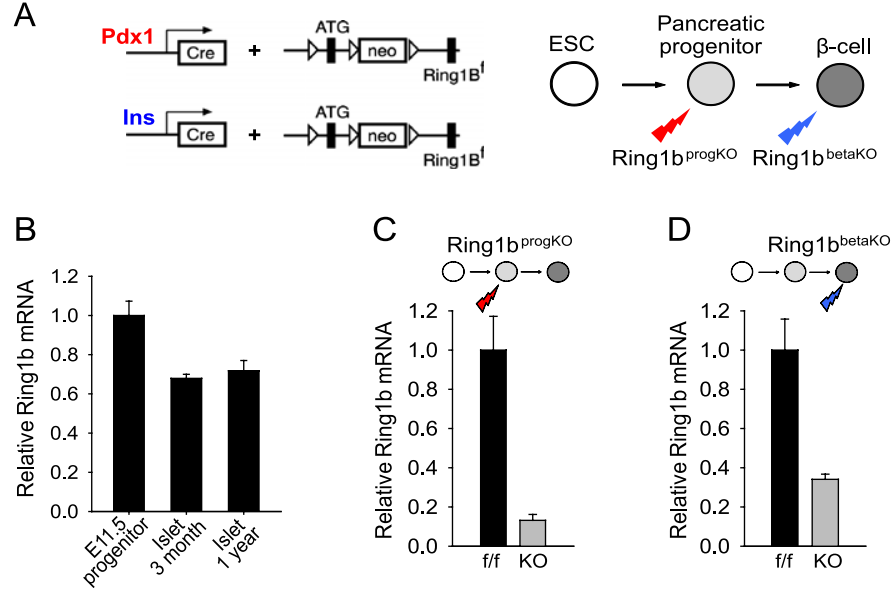

C Ring1b progko
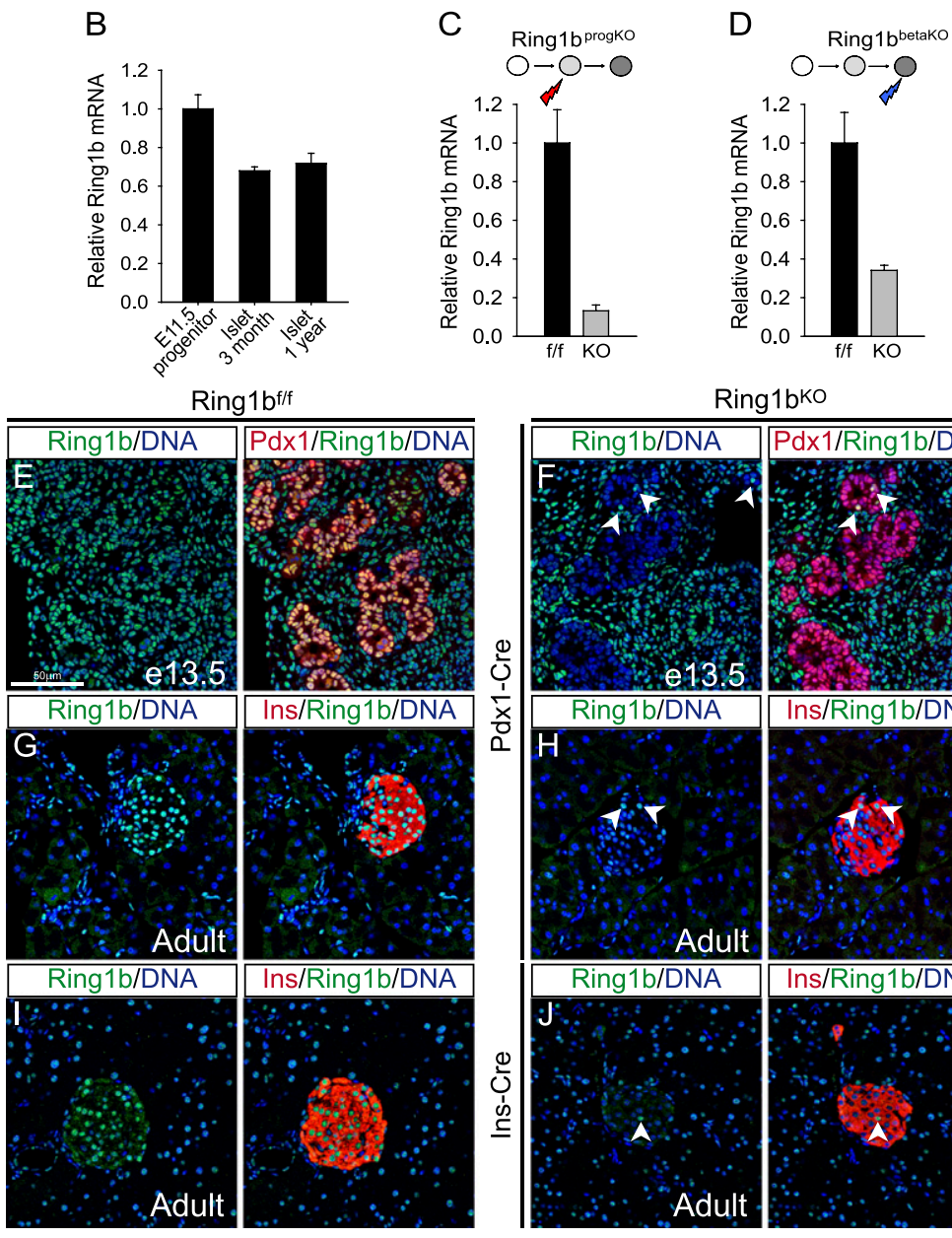

Ring1bko

Ring1b/DNA $/$ Pdx1/Ring1b/DNA

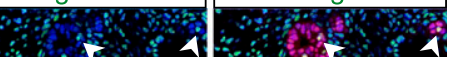

Figure 1. Stage-specific inactivation of $R$ ing $1 b$ in $\beta$-cell development. (A) Schematic of the Cre transgenic models used for Ring1b inactivation. Pdx1Cre inactivates Ring $1 b$ in embryonic multipotent pancreatic progenitors (Ring $\left.1 b^{\text {progKO }}\right)$ and Ins-Cre in lineage-committed $\beta$ cells (Ring $\left.1 b^{\beta K O}\right)$. (B) Ring1b is expressed in embryonic day 11.5 (E11.5) pancreatic progenitors $(n=2)$ and in islets from young (14 wk; $n=4)$ and 1 -yr-old $(n=2)$ mice. $(C, D)$ Ring $1 b$ is efficiently excised in Ring $1 b^{\text {progKO }}$ and Ring $1 b^{\beta K O}$ islets $(n=5)$. Levels were normalized for $A c t b$ mRNA and are expressed relative to $R i n g 1 b^{\mathrm{f} / \mathrm{f}}$ littermate controls. Note that $\beta$ cells represent $\sim 60 \%$ of islet cells. Error bars indicate the SEM. $(E, F)$ Immunofluorescence analysis of Ringlb (green), Pdxl (red), and Topro (blue) shows enriched Ring1b expression in the multipotent progenitor trunk domain of Ring $1 b^{\mathrm{f} / \mathrm{f}}$ E13.5 embryos $(E)$, whereas it is absent in Ring $1 b^{\text {progKO }}$ embryos $(F)$. $(G, H)$ Immunofluorescence analysis of Ringlb (green), insulin (red), and Topro (blue) shows enriched Ring $1 \mathrm{~b}$ expression in the pancreatic islets of 3-mo-old Ring $1 b^{\mathrm{f} / \mathrm{f}}$ animals $(G)$, whereas it is absent in Ring $1 b^{\text {progKO }}$ islets $(H)$. $(I, J)$ Same as $G$ and $H$, but for Ring $1 b^{\beta K O}$ islets. The white arrows indicate "escaper" cells that have not lost Ring1b.

tiling arrays to profile Ringlb binding in islet cells (Supplemental Table 1). We identified 448 genes bound by Ring $1 b$ in islets and, consistent with previous studies in embryonic stem (ES) cells, found that they form a subset of the genes that are enriched in $\mathrm{H} 3 \mathrm{~K} 27 \mathrm{me} 3$ in islets (Fig. 3B; Ku et al. 2008).

Of all of the Ring $1 \mathrm{~b}$ target genes, $5.6 \%$ were significantly up-regulated in Ring $1 b^{\text {progKO }}$ islets, in contrast to only $1.4 \%$ of non-Ring $1 \mathrm{~b}$ target genes $\left(P=1.2 \times 10^{-12}\right)$ (Fig. 3C). Gene set enrichment analysis (GSEA) consistently showed that Ringlb-bound genes were enriched among upregulated genes $(P<0.001)$ (Fig. 3D). Likewise, $28 \%$ of genes that were up-regulated Ring $1 b^{\text {progKO }}$ islets showed H3K27me3 enrichment in wild-type islets, indicating that they were PcG targets, whereas H3K27me3 enrichment was observed in $15 \%$ of all genes $\left(P=6.9 \times 10^{-11}\right)$. Thus, genes bound by Ringlb-and, more generally, PcG targets-were preferentially derepressed in Ring $1 b^{\text {progKO }}$ islets, although only a subset of Ring $1 \mathrm{~b}$ targets was perturbed.
We next selected 15 genes that were bound by Ring1b in islets (Fig. 3E), of which 10 showed up-regulation and five showed no change in Ring $1 b^{\text {progKO }}$ islets in the gene chip analysis, and confirmed these findings in all cases by quantitative RT-PCR (qRT-PCR) (Fig. 3F). All 15 Ring1b target genes were then examined in islets from adult Ring $1 b^{\beta K O}$ mice. In keeping with their normal glucose tolerance, the expression of Ringlb target genes was unperturbed (Fig. 3G). Thus, Ring1b deletion in pancreatic progenitors led to derepression of a subset of Ring $1 \mathrm{~b}$ target genes in differentiated islet cells, whereas no changes were encountered when Ring $1 b$ was deleted in lineagecommitted $\beta$ cells.

\section{Early Ring1b inactivation causes islet misexpression of neural and disallowed genes}

To further understand the role of Ring1b-dependent repression in pancreatic endocrine programming, we 
A

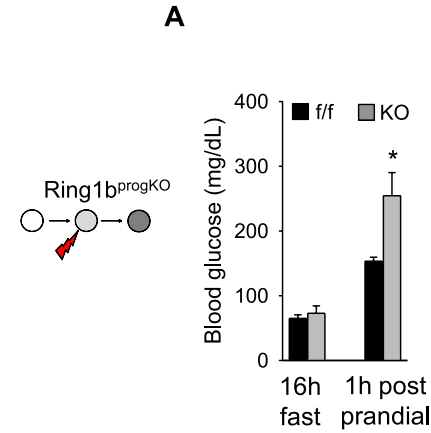

E
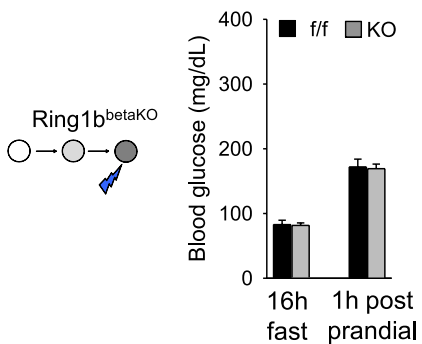

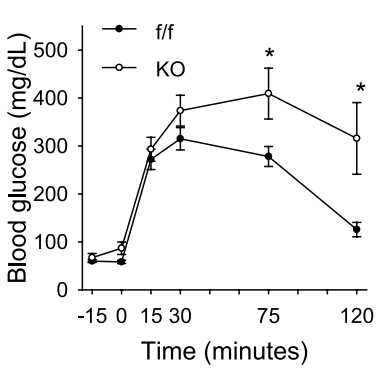

$\mathbf{F}$

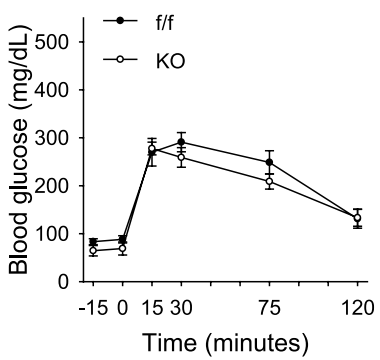

C

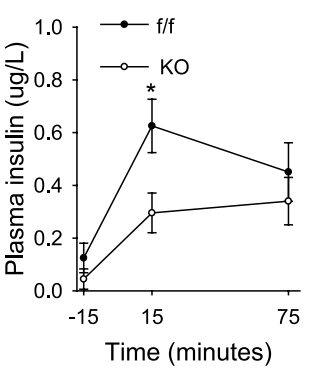

G

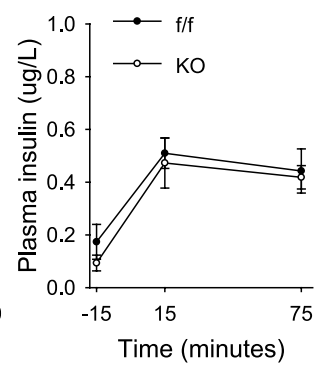

D

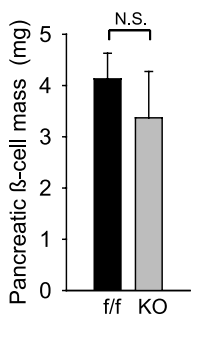

H

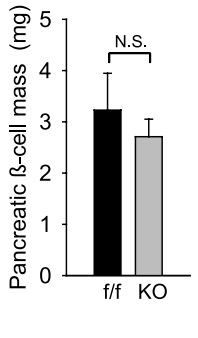

Figure 2. Early but not late inactivation of Ring1b leads to glucose intolerance. $(A, E)$ Post-prandial blood glucose is significantly increased in Ring $1 b^{\text {progKO }}(n=7)$ versus $R$ ing $1 b^{\mathrm{f} / \mathrm{f}}$ littermate controls $\left(n=10 ;{ }^{\star} P=0.0046\right)$, whereas no differences were observed in Ring $1 b^{\beta K O}(n=10)$ versus Ring $1 b^{\mathrm{f} / \mathrm{f}}$ littermate controls $(n=10) .(B, F)$ Impaired intraperitoneal glucose tolerance in $R$ ing $1 b^{\mathrm{progKO}}(n=7)$ versus Ring $1 b^{\mathrm{f} / \mathrm{f}}$ littermates controls $(n=8)$ but not in $\operatorname{Ring}_{1} b^{\beta \mathrm{KKO}}(n=8)$ versus $\operatorname{Ring} 1 b^{\mathrm{f} / \mathrm{f}}$ littermates controls $\left(n=7 ;{ }^{\star} P<0.05\right)$. $(C, G)$ Impaired insulin levels in response to an intraperitoneal glucose challenge in Ring $1 b^{\text {progKO }}(n=11)$ versus $\operatorname{Ring}^{\mathrm{f}} b^{\mathrm{f} / \mathrm{f}}$ littermate controls $(n=9)$ but not in Ring $1 b^{\beta \mathrm{KO}}$ mice $\left({ }^{\star} P=0.01\right) .(D, H)$ No significant differences in $\beta$-cell mass were observed between Ring $1 b^{\text {progKO }}(n=4)$ and Ring $1 b^{\mathrm{f} / \mathrm{f}}$ littermate controls $(n=4 ; P=0.54)$ or Ring $1 b^{\beta \mathrm{KO}}(n=3)$ and Ring $1 b^{\mathrm{f} / \mathrm{f}}$ littermate controls $(n=3 ; P=0.50)$. Error bars indicate the SEM.

focused on the subset of genes that were derepressed in Ring $1 b^{\text {progKO }}$ islets. This gene set was enriched in neural developmental regulators $\left(P=5.4 \times 10^{-7}\right)$ (Fig. 4A) and in genes that showed a tissue-specific gene expression pattern in the brain and cerebellum $(P<0.05)$ (Fig. 4B; Supplemental Fig. 3A). Thus, neural-enriched genes that are normally silent in islets, such as $R a b 3 c$, $M k x$, and Kcnj3, were up-regulated in Ring $1 b^{\text {progKO }}$ islets. Of note, Npy is normally detected in scarce control $\beta$ cells but was expressed in a sixfold higher number of Ring $1 b^{\text {progKO }} \beta$ cells (Supplemental Fig. 3B-D). Thus, Ring $1 b$ deletion in pancreatic progenitors causes abnormal islet expression of neural-enriched and neuroendocrine genes.

We recently showed that " $\beta$-cell disallowed genes"-a term that refers to genes that are selectively inactive in $\beta$ cells and have been proposed to be deleterious for $\beta$-cell function (Pullen et al. 2010; Thorrez et al. 2011)—are selectively targeted by PcG-mediated repression during late differentiation (van Arensbergen et al. 2010). The current analysis showed that this set of genes was also enriched among genes that are up-regulated in Ring $1 b^{\text {progKO }}$ islets $(P<0.001)$ (Fig. 4C). Thus, during embryonic development, Ring $1 \mathrm{~b}$ establishes repressed states that refine the neuroendocrine phenotype of islet cells and prevent inappropriate gene activity in differentiated cells.

\section{Early Ringlb inactivation prevents repression} of de novo Ring1b targets

We next examined why only a subset of Ring1b targets was derepressed in Ring $1 b^{\text {progKO }}$ islets. We reasoned that if Ring $1 \mathrm{~b}$ is solely required to establish repressed chromatin rather than maintain it, genes that were already targeted by Ring $1 \mathrm{~b}$ in pluripotent cells prior to inactivation of Ring $1 b$ in pancreatic progenitors should not be affected in Ring $1 b^{\text {progKO }}$ islets. In contrast, genes that are targeted by Ring $1 b$ de novo during pancreas development should be perturbed if Ring $1 b$ is inactivated at this early stage.

To identify Ring $1 b$ targets that are established de novo during embryonic development, we profiled Ring1b in ES cells. We found that of all 448 islet Ring1b targets, 90 (20.1\%) were not bound in ES cells (Supplemental Table 1). These were classified as de novo Ringlb targets (Fig. 5A). In keeping with our predictions, de novo islet Ring $1 \mathrm{~b}$ targets were more frequently up-regulated in Ring $1 b^{\text {progKO }}$ islets than targets that were already bound by Ring $1 \mathrm{~b}$ in ES cells (12.2 vs. $3.9 \%$, respectively; $P=0.005$ ) (Fig. 5B). Likewise, GSEA showed that de novo Ringlb targets were preferentially enriched among up-regulated genes (Fig. 5C). Thus, loss of Ring $1 \mathrm{~b}$ at the pancreatic progenitor stage preferentially affects genes that are targeted de novo by PcG proteins during embryogenesis, rather than those 
A

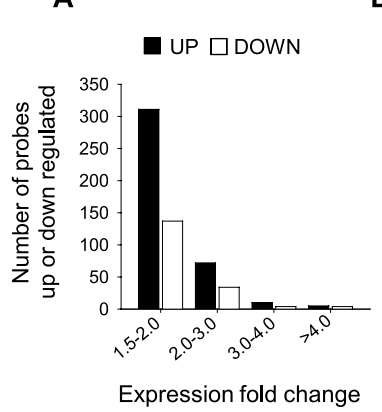

E

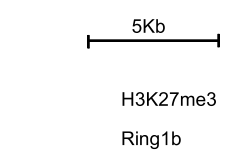

$\mathbf{F}$

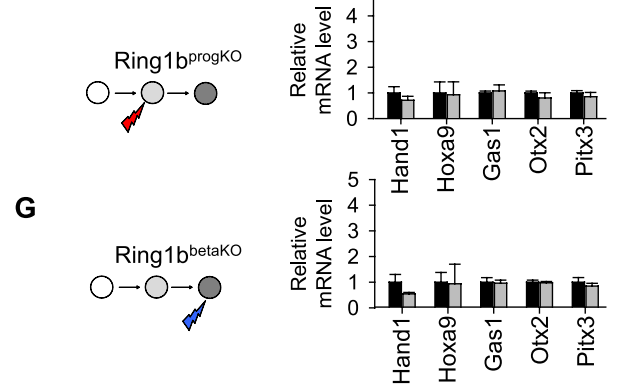

C

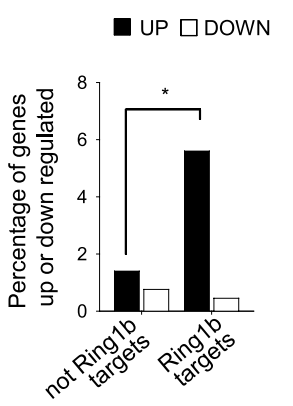

D

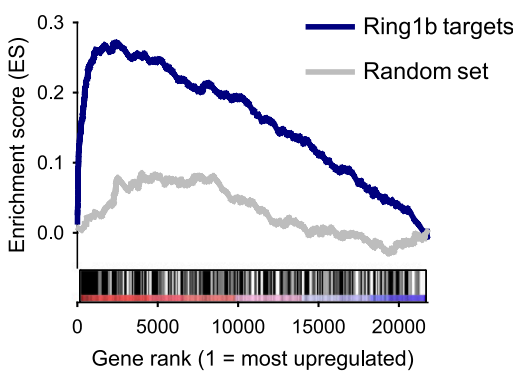

Ring1b targets upregulated in the Ring1 $b^{\text {progko }}$
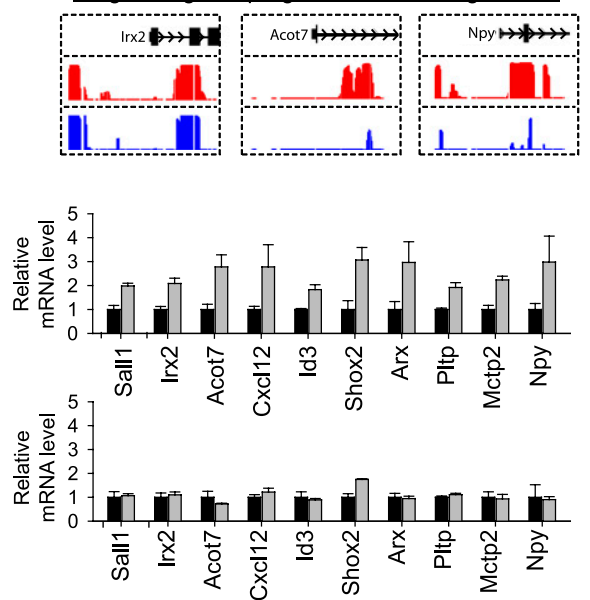

Figure 3. Derepression of Ring $1 b$ targets in Ring $1 b^{\text {progKO }}$ islets. $(A)$ Ring $1 b^{\text {progKO }}$ islets exhibit a transcriptional derepression phenotype. GeneChip expression analysis was performed with islets from adult Ring $1 b^{\text {progKO }}$ mice $(n=3)$ and control littermates $(n=3)$. Probes showing at least 1.5 -fold up-regulation or down-regulation at $P<0.05$ in Ring $1 b^{\text {progKO }}$ islets were binned in four groups according to their fold changes. Up-regulated probes were significantly more common than down-regulated probes $\left(P<2.2 \times 10^{-16}\right)$. $(B)$ Venn diagram showing the overlap of H3K27me3 targets and Ring1b targets in islets (the overlap is 407 out of 448 ). (C) Ring1b targets were preferentially up-regulated in Ring $1 b^{\text {progKO }}$ islets. Transcript up-regulation in Ring $1 b^{\text {progKO }}$ islets was approximately fourfold more frequent in Ringlb-bound than nonbound genes $\left(\left[^{*}\right] P=1.2 \times 10^{-12}\right)$, whereas transcript down-regulation did not differ between the two groups. (D) GSEA showed that genes bound by Ringlb in islets were enriched among genes that showed a high expression fold change in Ring $1 b^{\text {progKO }}$ islets $(P<0.001)$. An analogous enrichment analysis is shown for a random gene set of the same size. $(E)$ H3K27me3 and Ring1b-binding patterns in mouse islets for selected Ring1b target genes that were either up-regulated or unperturbed in Ring $1 b^{\text {progKO }}$ islets. $(F, G)$ qRT-PCR assessment of direct Ring1b target genes in Ring $1 b^{\text {progKO }}(F$, gray bars; $n=3)$ and Ring $1 b^{\beta K O}(G$, gray bars; $n=3)$ islets. Levels were normalized for Actb mRNA and are expressed relative to Ring $1 b^{\mathrm{f} / \mathrm{f}}$ littermate controls (black bars; $n=3$ ). This confirmed that many direct Ringlb target genes were unaffected in both Ringlb-deficient models (left panels), whereas a subset of targets were selectively up-regulated in Ring $1 b^{\text {progKO }}$ but not Ring $1 b^{\text {BKO }}$ islets (right panels). Error bars indicate the SEM.

that were already targeted during earlier stages. Consistent with this idea, islet Ring $1 \mathrm{~b}$ targets that showed upregulation in Ring $1 b^{\text {progKO }}$ islets acquired $\mathrm{H} 3 \mathrm{~K} 27 \mathrm{me} 3$ de novo throughout normal pancreas development, whereas islet Ring $1 \mathrm{~b}$ targets that were unaffected in Ring $1 b^{\text {progKO }}$ mice already displayed H3K27me3 enrichment at the pancreatic progenitor stage (Fig. 5D,E; Supplemental Fig. 4). Thus, Ring $1 b$ inactivation in pancreatic progenitors preferentially alters the expression of genes that are targeted de novo by Ringlb during late pancreatic development while leaving genes that are targeted by Ring $1 b$ prior to Ring $1 b$ deletion in pancreatic progenitors largely unperturbed. These findings further support a role for Ring $1 \mathrm{~b}$ in establishing rather than maintaining $\beta$-cellrepressive programs.

\section{Silencing of Ring $1 b$ targets is mitotically inherited in Ring $1 \mathrm{~b}^{\beta K O} \beta$ cells}

The observation that Ringlb targets are derepressed after gene ablation in progenitors but not after gene ablation in differentiated islets could theoretically reflect a defect in mitotic transmission of repressed states, given that more rounds of cell divisions occur from gene deletion to analysis in the early ablation model. To address this possibility, we generated immortalized $\beta$-cell lines from Ring $1 b^{\text {progKO }}$ and Ring $1 b^{\beta \mathrm{KKO}}$ mice (Fig. 6A) using RIPTAg transgenic mice expressing the SV40 large T-antigen in $\beta$ cells (Hanahan 1985). $\beta$-Cell lines were maintained in culture for $>20$ estimated cell divisions. We analyzed five cell lines from separate animals for each genotype and tested six 
A

\begin{tabular}{ll} 
Top GO categories upregulated & $\mathbf{p}$-value \\
\hline nervous system development & $\mathrm{p}=5.4 \times 10^{-7}$ \\
developmental process & $\mathrm{p}=3.3 \times 10^{-6}$ \\
neurogenesis & $\mathrm{p}=7.7 \times 10^{-5}$ \\
tissue development & $\mathrm{p}=1.1 \times 10^{-4}$ \\
organ development & $\mathrm{p}=1.3 \times 10^{-4}$ \\
\hline
\end{tabular}

B

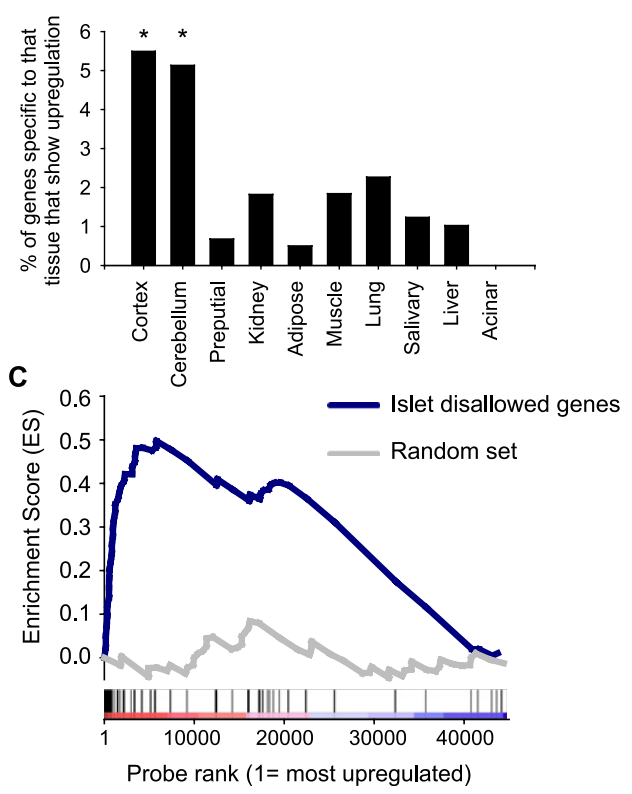

Figure 4. Misexpression of neural and disallowed genes in Ring $1 b^{\text {progKO }}$ islets. $(A)$ The top categories of gene ontology analysis of up-regulated genes in Ring $1 b^{\text {progKO }}$ islets. $P<0.05$ after Benjamini correction for all uncorrected $P$-values shown in the table. $(B)$ Genes that were up-regulated in Ring $1 b^{\text {progKO }}$ islets were frequently neural-specific $\left(\left[{ }^{\star}\right] P<0.05\right.$ for all comparisons of cortex or cerebellum with all other tissues). Tissue-specific genes were defined as those expressed in that tissue and no more than two other tissues. $(C)$ GSEA showed that genes that have been classified as disallowed in $\beta$ cells were enriched among genes up-regulated in Ring $1 b^{\text {progKO }}$ islets $(P<$ $0.001)$. An analogous enrichment analysis is shown for a random gene set of the same size $(P=0.661)$.

genes that were up-regulated in the Ring $1 b^{\text {progKO }}$ islets. In keeping with our observations in native islets, five out of six of these genes were consistently up-regulated in the Ring $1 b^{\text {progKO }} \beta$-cell lines (Fig. 6B-E; Supplemental Fig. 5). Remarkably, all of these genes remained repressed in Ring $1 b^{\beta \mathrm{KO}} \beta$-cell lines, despite multiple rounds of cell divisions. Thus, Ring $1 b$-deficient $\beta$ cells are capable of mitotically propagating repressed states that were established in a Ringlb-dependent manner during pancreatic development. This finding further supports that Ring $1 \mathrm{~b}$ is not essential to maintain transcriptional repression of its target genes in differentiated $\beta$ cells.

Ring $1 b$ is required in pancreatic progenitors for target gene DNA methylation in differentiated islet cells

We next assessed molecular mechanisms that could underlie the maintenance of repression in the Ring $1 b^{\beta K O}$ $\beta$-cell lines in genes that showed up-regulation in the Ring $1 b^{\text {progKO }} \beta$-cell lines. We first confirmed that Ring $1 \mathrm{~b}$ was bound to these genes in the cell lines (Fig. 7A). Interestingly, the related protein Ringla was not strongly enriched at these same genes in control $\beta$ cells, and, importantly, neither Ringla nor Bmil (another PRC1 subunit) showed increased binding in mutant islets (Fig. 7B; Supplemental Fig. 6A). This result argued that gene silencing in Ring $1 b^{\beta K O} \beta$ cells was unlikely to be maintained by PcG-mediated repressive mechanisms.

We next hypothesized that DNA methylation was responsible for maintaining repression in control and Ring $1 b^{\beta K O} \beta$ cells. Accordingly, methylated DNA immunoprecipitation (MeDIP) showed that Ringlb targets had a decreased level of DNA methylation in Ring $1 b^{\text {progKO }}$ cells compared with control and Ring $1 b^{\beta K O} \beta$ cells (Fig. 7C). Furthermore, H3K9me3, a histone mark in certain cases associated with DNA methylation (Hashimoto et al. $2010)$, displayed a similar trend in Ring $1 b^{\text {progKO }} \beta$ cells (Supplemental Fig. 6B). These findings thus suggest that Ringlb-independent repressive mechanismsnamely, DNA methylation and $\mathrm{H} 3 \mathrm{~K} 9 \mathrm{me} 3$ - are associated with the maintenance of a repressed state that is initiated in a Ringlb-dependent manner in pancreatic progenitors.

\section{Discussion}

Several distinct mechanisms are known to promote repressed chromatin states. The specific role that each mechanism plays in controlling cell fate decisions, differentiation, and long-term phenotypic maintenance, however, remains elusive. In the present study, we showed that Ringlb acts in pancreatic embryonic progenitors to specify the transcriptional program of differentiated $\beta$ cells. We demonstrated that Ring $1 \mathrm{~b}$ function in pancreatic progenitors is essential to establish transcriptional repression and DNA methylation of selected target genes in differentiated $\beta$ cells, whereas after cells have differentiated, Ring $1 \mathrm{~b}$ is no longer required to maintain the repression of these same target genes. The data therefore indicate that during lineage-specific differentiation, Ring1b bookmarks genes that are later locked in a stably repressed state through Ringlb-independent mechanisms.

\section{Ring $1 b$ is used to refine the transcriptional program of differentiated $\beta$ cells}

Earlier studies showed that the differentiation of $\beta$ cells entails the selective removal of PcG-mediated repression from a core set of neural regulatory genes (van Arensbergen et al. 2010). This in turn enables the activation of a transcriptional program in $\beta$ cells that is remarkably similar to that of ectodermally derived neural cell types (van Arensbergen et al. 2010). The current findings suggest that during the differentiation of $\beta$ cells, PcG-mediated repression is also employed to suppress the activation of selected neural genes. Plausibly, this fulfills a need to repress the indiscriminate activation of neural 
van Arensbergen et al.
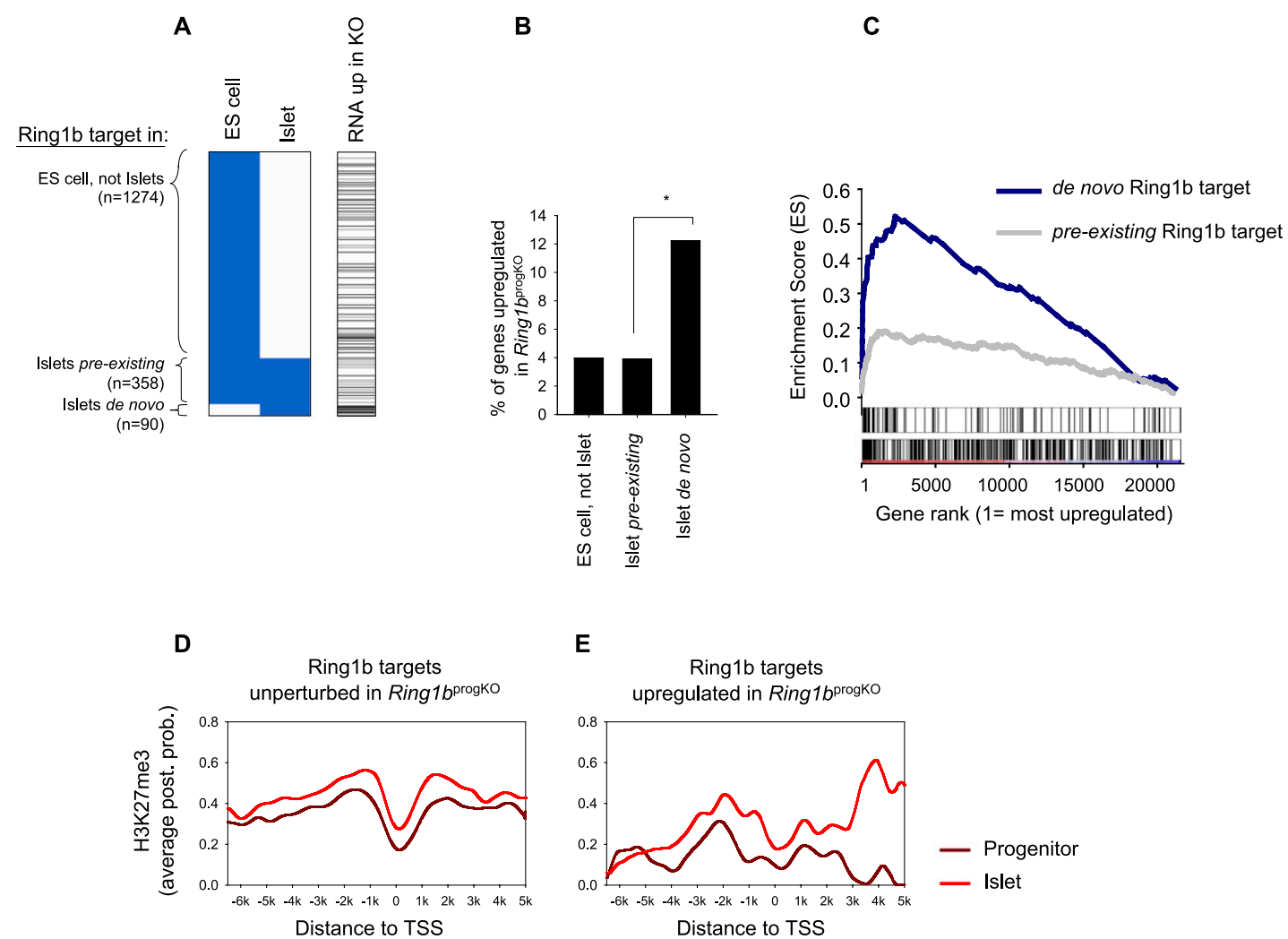

Figure 5. Early loss of Ring1b leads to misexpression of de novo Ring1b targets. (A) Cluster representation of Ring1b-bound genes (blue) based on binding in ES cells and islets. The right column shows genes up-regulated in Ring $1 b^{\text {progKO }}$ islets in black. $(B)$ Percentage of up-regulated genes among the three groups of Ring $1 b$ targets. De novo Ring $1 b$ targets are more frequently up-regulated than preexisting Ring $1 \mathrm{~b}$ targets $\left(\left[{ }^{\star}\right] P=0.005\right) .(C)$ GSEA of de novo and pre-existing islet Ring $1 \mathrm{~b}$ targets among genes ranked according to their fold change in expression in Ring $1 b^{\text {progKO }}$ islets. Islet de novo Ring1b targets displayed strong enrichment among upregulated genes $(P<0.001$, maximum enrichment score $=0.52)$, while weaker enrichment was observed for pre-existing Ringlb targets $(P=0.0011$, maximum enrichment score $=0.19)$. The two bars below the graph depict the rank position of de novo $($ top $)$ and pre-existing (bottom) Ring1b targets. $(D, E) \mathrm{H} 3 \mathrm{~K} 27 \mathrm{me} 3$ enrichment in wild-type pancreatic progenitors (dark red) and wild-type islets (light red) for Ringlb targets that were unperturbed $(n=418)(D)$ or up-regulated $(n=28)(E)$ in $R$ ing $1 b^{\text {progKO }}$ islets. Enrichment is quantified as average posterior probability (post. prob.). Plots that show H3K27me3 as a fold enrichment value show the same pattern (Supplemental Fig. 4).

genes in cells that express many neural transcriptional activators. Existing data thus suggest that during pancreas development, PcG-dependent repression is selectively removed from neuroendocrine regulatory genes that promote islet cell differentiation, although, concomitantly, PcG-mediated repression is used to repress neural-enriched genes that do not form part of the pancreatic endocrine program.

Epigenomic profiling in pancreatic islet cells has also shown that PcG-mediated repression targets disallowed genes in $\beta$ cells, defined as genes that are selectively absent and potentially deleterious for $\beta$ cells (Thiel and Schuit 2008; Pullen et al. 2010; van Arensbergen et al. 2010). The present study shows that Ringlb not only binds to such genes, but is also required in pancreatic progenitors to establish their repression in $\beta$ cells.

The transcriptional changes observed in Ring $1 b^{\text {progKO }}$ islet cells led to abnormal glucose intolerance due to defective $\beta$-cell insulin secretory function. One of the disallowed genes that we identified as up-regulated in
Ringlb-deficient islets was $A \cot 7$, encoding a type II acylCoA thiosterase. Acot7 displays a preference for mediumchain-length acyl-CoA esters (Kirkby et al. 2010), which are implicated in the gating of ATP-sensitive $\mathrm{K}^{+}$channels and the control of insulin granule exocytosis (Corkey et al. 2000). The absence of Acot7 from normal $\beta$ cells may thus allow acyl-CoA to reach high levels, modulating both glycolytic flux and late events in insulin granule release. Consistent with this prediction, forced overexpression of $A \cot 7$ in $\beta$-cell lines leads to impaired glucose and KCl-stimulated insulin secretion (GA Rutter and T) Pullen, unpubl.). This enzyme is thus a plausible candidate contributor to the defective secretion in Ring $1 b^{\text {progKO }}$ mice. Another gene that is up-regulated in Ring1bdeficient islets is $N p y$, which is known to suppress cAMP levels and inhibit insulin secretion and can therefore also contribute to the in vivo phenotype of Ring $1 b^{\text {progKO }}$ mice (Wang et al. 1994; Myrsen-Axcrona et al. 1997). In addition to Acot7 and Npy, we do not exclude roles of other up-regulated genes that could contribute to abnormal 
A

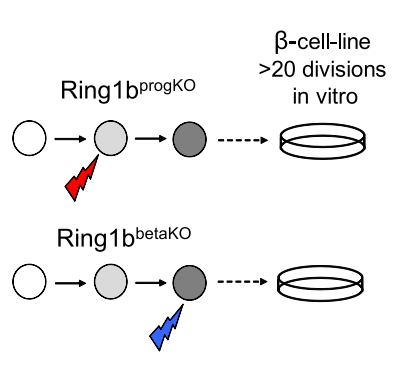

B

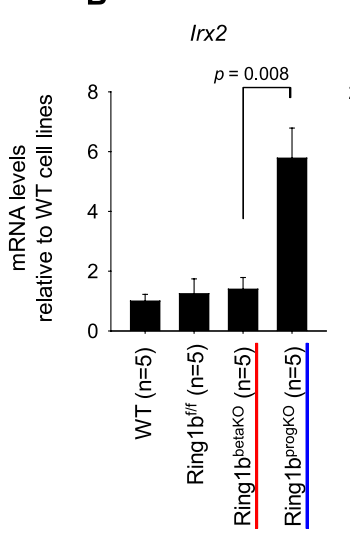

C

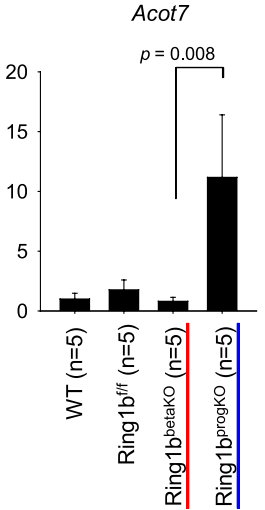

D

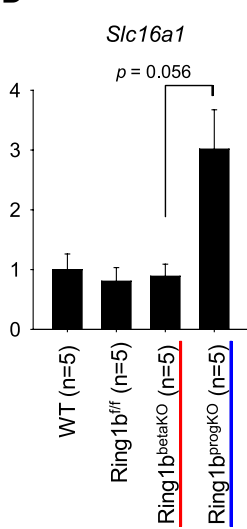

E

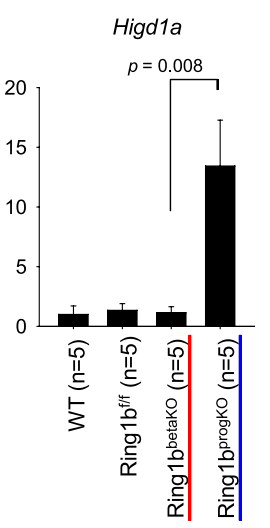

Figure 6. Mitotic inheritance of repression patterns. (A) Schematic representing the generation of $\beta$-cell lines. We crossed Ring $1 b^{\text {progKO }}$ and Ring $1 b^{\beta K O}$ mice with RIP-TAg transgenics to generate insulinomas. Ring $1 b$-deficient $\beta$-cell lines were established from individual adult animals per genotype. $(B-E)$ qRT-PCR analysis of Irx2, Acot7, S1c16a1, and Higd1a in cell lines established from wild-type $(n=5)$, Ring $1 b^{\mathrm{f} / \mathrm{f}}$ littermate control $(n=5)$, Ring $1 b^{\beta \mathrm{KO}}(n=5)$, and Ring $1 b^{\text {progKO }}(n=5)$ mice. Ring $1 b^{\text {progKO }}$ cell lines displayed derepression of Ringlb targets, whereas repression was maintained in the Ring $1 b^{\beta K O}$ cell lines despite $>20$ rounds of cell division. Error bars indicate the SEM.

$\beta$-cell function due to a collective transcriptional defect of differentiated $\beta$ cells.

\section{A developmental bookmarking function of Ring1b}

PcG complexes control numerous developmental functions, including anteroposterior patterning, gastrulation, $\mathrm{X}$ inactivation, stem cell differentiation, and genomic imprinting (Sparmann and van Lohuizen 2006; Margueron and Reinberg 2011). Furthermore, PcG complexes target developmental regulatory genes, consistent with a pivotal

A

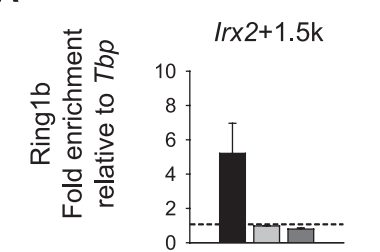

B

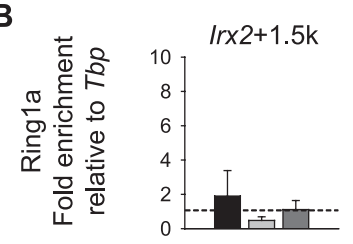

C

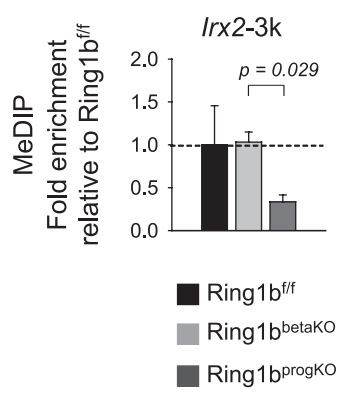

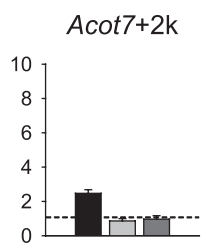
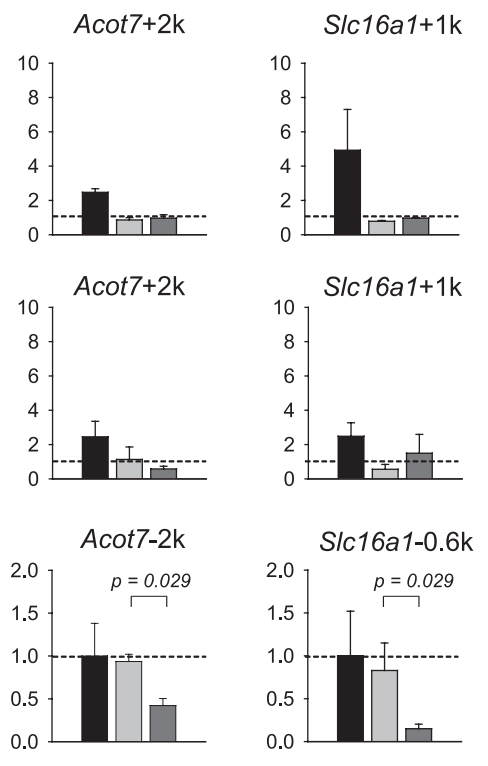

role in development (Boyer et al. 2006; Bracken et al. 2006; Lee et al. 2006). However, the precise spatiotemporal roles of PcG proteins in lineage-specific differentiation programs are only beginning to be understood.

One limitation to understanding PcG-dependent programming has been that its deficiency often leads to premature senescence or cell death, resulting in the abrogation of the lineage of interest. Recent studies have nevertheless revealed how the PcG subunit Ezh2 controls the differentiation of lineage-specific precursors. Thus, in skin progenitors, Ezh2 deficiency leads to the activation
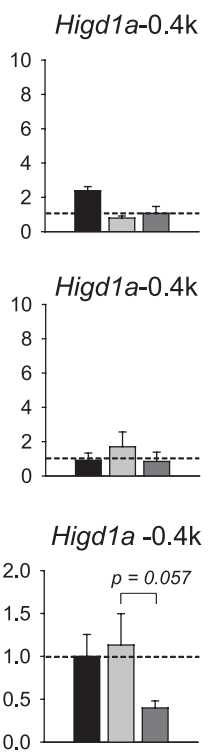

Figure 7. Ring $1 \mathrm{~b}$ is required in pancreatic progenitors for target gene DNA methylation in differentiated islet cells. $(A, B)$ Chromatin immunoprecipitation (ChIP) analysis of Ring $1 \mathrm{~b}$ and Ringla occupancy at direct Ring $1 \mathrm{~b}$ targets in cell lines established from Ring $1 b^{\mathrm{f} / \mathrm{f}}$ littermate controls (black bar; $n=3$ ) and Ring $1 b^{\beta \mathrm{KO}}$ (light-gray bar; $n=3$ ) and Ring $1 b^{\text {progKO }}$ (dark-gray bar; $n=3 \mid$ mice. The dotted line indicates enrichment $=1 .(C)$ As in $A$ and $B$, but here, MeDIP was performed $(n=4)$. Enrichments are shown relative to controls after normalization for Tbp. Error bars indicate the SEM. 
of genes that promote differentiation, whereas the inactivation of Ezh2 in skeletal muscle or heart progenitors causes altered lineage differentiation (Ezhkova et al. 2009; Juan et al. 2011; Delgado-Olguin et al. 2012). Furthermore, Ezh2 deficiency causes altered cell fate decisions of foregut endoderm multipotent progenitors $(\mathrm{Xu}$ et al. 2011). These results have highlighted a crucial role for Ezh2 in establishing the transcriptional fidelity of organ-specific progenitors and their offspring.

In the present study, we exploited the fact that Ring $1 \mathrm{~b}$ deficiency does not disrupt pancreatic organogenesis or cell growth to understand stage-specific functions of PcGmediated repression during lineage programming. Our results uncouple the mechanisms that establish and maintain the repression of a discrete set of genes in a cellular lineage. Ring1b was essential to set up repression when it first associated with specific loci, whereas repression of those loci thereafter became Ringlb-independent despite maintained Ring1b occupancy. This transient function of Ringlb in pancreatic progenitors was linked to the acquisition of DNA methylation at target loci in terminally differentiated cells. Based on these findings, we propose a model in which Ringlb marks genes for repression as lineages are formed during pancreas organogenesis, and once the terminally differentiated $\beta$-cell lineage is established, its transcriptional state is maintained through alternate mechanisms.

\section{Ring $1 b$ is not required to maintain the differentiated $\beta$-cell phenotype}

Ringlb was dispensable to maintain the transcriptional program of differentiated $\beta$ cells. Interestingly, Ezh2 deficiency in differentiated $\beta$ cells only causes a cell growth phenotype that appears completely rescued by the inactivation of the cell cycle regulator Cdkn2a (Chen et al. 2009), consistent with other studies showing a critical role of PcG-dependent repression in controlling the growth of differentiated cells (e.g., Jacobs et al. 1999; Bracken et al. 2007). On the other hand, existing studies have shown diverse PcG-dependent functions during development to either control cell fate choices or the timing of differentiation or, as shown in the present study, refine the transcriptional program of differentiated cellular offspring. To our knowledge, however, no study has demonstrated that the inactivation of a PcG subunit in mature cells results in a global modification of its transcriptional program. This contrasts with observations that removal of DNA methylation in differentiated $\beta$ cells causes transcriptional perturbations that cause cellular transdifferentiation events, suggesting that DNA methylation is a dominant mechanism for maintenance of cell identity in differentiated $\beta$ cells (Dhawan et al. 2011). Taken together, existing data support a prominent role for PcG-mediated repression during developmental programming of cellular identities, whereas direct evidence for PcG-dependent maintenance of adult terminally differentiated phenotypes is still lacking.

More generally, genetic experiments have provided insight into the complexity of epigenetic regulation of development. They illustrate how different regulatory subunits play highly stage-dependent roles in lineage differentiation. A detailed understanding of the specialized functions of epigenetic regulators, together with ongoing efforts to generate a plethora of compounds that target this class of proteins, should provide opportunities to manipulate differentiation programs for disease modeling and therapeutics.

\section{Materials and methods}

Mouse models

Mice with Ring $1 b$ LoxP alleles as well as RipTAg, Ins-Cre, and Pdx1-Cre transgenic lines have been described (Hager and Hanahan 1999; Herrera 2000; Gu et al. 2002; Cales et al. 2008). All experiments were approved by the Institutional Animal Care Committee of the University of Barcelona.

\section{RNA analysis}

Mouse pancreatic islets were isolated from 12- to 14-wk-old male mice as described previously (Luco et al. 2008). Total RNA was extracted from pancreatic islet preparations of three individual male animals for each genotype using Trizol (Invitrogen). RNA integrity was verified with a 2100 Bioanalyzer (Agilent), and labeled cRNA was hybridized to Affymetrix Mouse Genome 4302.0 arrays. Data normalization was performed as described (van Arensbergen et al. 2010). Expression data on other mouse tissues were described previously (van Arensbergen et al. 2010).

\section{Chromatin immunoprecipitation (ChIP)}

ChIPs were performed essentially as described (van Arensbergen et al. 2010). In short, pancreatic islets or mouse ES cells (CGR8) (Skoudy et al. 2004) were fixed in $1 \%$ formaldehyde for $10 \mathrm{~min}$, after which nuclei were purified and sonicated using a Bioruptor (Diagenode) to a length of 200-1000 base pairs (bp). Samples were precleared with protein A+G-Sepharose (1:1) and immunoprecipitated with rabbit anti-Ring1b (Garcia et al. 1999), rabbit antiRing1a (Schoorlemmer et al. 1997), rabbit anti-H3K9me3 (Abcam, 8898), rabbit anti-H3K27me3 (Upstate Biotechnology, 07-449), and mouse anti-Bmil (Millipore, 05-637) overnight at $4^{\circ} \mathrm{C}$. Immune complexes were collected by adsorption to protein $\mathrm{A}+\mathrm{G}-$ Sepharose for $2 \mathrm{~h}$ at $4^{\circ} \mathrm{C}$. Beads were washed, and immunocomplexes eluted prior to DNA purification with Qiaquick columns (Qiagen).

For tiling array experiments, ChIP and input DNA were amplified as described previously using the Sigma GenomePlex WGA2 kit while adding dUTPs to a final concentration of $0.4 \mathrm{mM}$ during the amplification reaction to enable subsequent fragmentation (van Arensbergen et al. 2010). We fragmented 6-7.5 $\mu \mathrm{g}$ of DNA, labeled it using the Affymetrix GeneChip WT Double-Stranded DNA Terminal Labeling kit, and hybridized it to GeneChip Mouse Promoter 1.0R arrays. Primary processing of data was performed as described (van Arensbergen et al. 2010). H3K27me3 GeneChip data sets from ES cells, purified pancreatic embryonic progenitors, and islets were described previously (van Arensbergen et al. 2010).

\section{$\mathrm{MeDIP}$}

Immunoprecipitation of methylated DNA was performed as described previously with minor modifications (Weber et al. 
2005). In short, we isolated the DNA from $\sim 3$ million cells using a Proteinase K digest followed by phenol-chloroform extraction. Four micrograms of DNA was sonicated in $500 \mu \mathrm{L}$ of TE buffer using a Bioruptor (Diagenode). DNA was then denatured in boiling water for $10 \mathrm{~min}$ and cooled on ice. The DNA was then diluted in $500 \mu \mathrm{L}$ of $2 \times$ precipitation buffer, and $2 \mu \mathrm{L}$ of mouse 5-methylcytidine antibody (Eurogentec, BI-MECY-0100) was added. From this step on, samples were treated as in the normal ChIP procedure described above.

\section{Statistical and integrated data analysis}

Significant enrichment in GeneChip ChIP experiments relative to input DNA was determined using Cisgenome (Ji et al. 2008). We applied a hidden Markov model as described (Ji and Wong 2005) and used a posterior probability cutoff of 0.5 in at least five continuous probes. Using identical criteria, $<0.05 \%$ of sites detected with Ring $1 \mathrm{~b}$ antibodies were observed in IgG control ChIP experiments in pancreatic acinar tissue. Enriched intervals were mapped to RefSeq genes when located within 2000 bp of transcriptional start sites.

Differential RNA expression was assessed using the ANOVA statistical analysis of the Partek software package. Genes were considered differentially expressed with a fold difference of $>1.5$ and a $P$-value $<0.05$. The presence and absence values for expression in other mouse tissues used for comparisons were determined as described previously (van Arensbergen et al. 2010)

The Database for Annotation, Visualization, and Integrated Discovery (DAVID) functional annotation tool was used to study the overrepresentation of annotation terms using all RefSeq genes as the background (Huang et al. 2009). Nonredundant gene ontology categories from the top "molecular function" and "biological process" terms were selected.

GSEA was performed on preranked gene expression data sets using the default weighted enrichment (Subramanian et al. 2005). Significance of the enrichment was assessed using 1000 permutations.

Differences in glucose, insulin, $\beta$-cell mass, and gene-specific expression in isolated islets were examined with Student's twosided $t$-test. In the $\beta$-cell line studies, a Wilcoxon test was used to account for the nonnormal distribution of the data. When a single $P$-value is given for several comparisons, it represents the $P$-value for the least significant of the comparisons.

Differences in frequency distributions were assessed in $\mathrm{R}$ using Pearson's $\chi^{2}$ test with Yates' continuity correction, except for results in Figure 4B, where Fisher's exact test was used because several entries in the table were smaller than five.

\section{qPCR analysis}

qPCR of reverse-transcribed RNA, ChIP, or MeDIP samples was performed on a 7300 Real-Time PCR system (Applied Biosystems) using the Power SYBR Green reagent (Applied Biosystems). Quantities were determined using the $2^{-\Delta \Delta \mathrm{Ct}}$ method. A full list of the primers used is provided in Supplemental Table 2.

\section{Immunofluorescence}

Embryos were collected at indicated times and processed for immunofluorescence analysis of paraffin-embedded pancreas as previously described (Maestro et al. 2003). The primary antibodies were guinea pig anti-insulin (1:5000; C. Van Schravendijk), rabbit anti-glucagon (1:200; Dako), rabbit anti-NPY (1:1000; Sigma, N9528), goat anti-PDX1 (1:1000; Abcam, ab47383), and rabbit antiRing1b (1:1000) (Garcia et al. 1999).

\section{Physiological tests}

For meal tests, male age-matched animals were fasted for $16 \mathrm{~h}$ overnight, and blood glucose was measured before and $1 \mathrm{~h}$ after refeeding. For glucose tolerance tests, fasted animals were injected intraperitoneally with $2 \mathrm{mg}$ of glucose per kilogram of body weight, and glucose levels were tested from tail blood at 0 , $15,30,75$, and $120 \mathrm{~min}$ after injection. Glucose was measured using the Glucocard G+ meter (Menarini Diagnostics). Insulin ELISA was performed using the Insulin ELISA kit of Mercodia (catalog no. 10-1247-01) and were read using a Synergy HT Multimode microplate reader (BioTek). Control littermates were $R$ ing $1 b^{\mathrm{f} / \mathrm{f}}$ littermates without the Cre transgene.

\section{$\beta$-Cell mass analysis}

The pancreases of 6-mo-old mice were dissected, weighed, folded to reduce their length, fixed, and embedded in OCT. Cryosections $(6 \mu \mathrm{m})$ were obtained at $30-\mu \mathrm{m}$ intervals throughout the organs. Approximately 60-70 cryosections were obtained from each pancreas. Immunofluorescence for DAPI and insulin was performed at each fifth slice. Images were taken by automated capturing and reconstruction of $\sim 50$ frames (Leica DMI 600B). Insulin-positive area and total tissue area were determined with in-house developed ImageJ macros and are available on request. In short, after manual curation of the merged RGB images, total tissue surface was determined by binarizing a diffused image for DAPI. $\beta$-Cell surface was determined by binarizing the insulin signal based on its relative intensities compared with the other two channels. These binarized images were then again manually curated, after which the $\beta$-cell mass was obtained by multiplying the ratio of the $\beta$-cell surface to total surface with the pancreas weight.

\section{Ring1b-deficient $\beta$-cell lines}

We performed crosses to generate mice that carried a RIP-TAg transgene alone or were, in addition, homozygous for the Ring1bLoxP allele and carried either Ins-Cre, Pdx1-Cre, or no Cre transgene. We dissected $\beta$-cell tumors from 10- to 14-wk-old mice when they showed a basal blood glucose level $<25 \mathrm{mg} / \mathrm{dL}$. Tumors were rinsed in PBS and then ruptured to release the inner cells. These cells were transferred to 20 separate 96 -well plates, each containing $\sim 10,000$ cells. Cells were monitored for proliferation and emergence of fibroblasts, and based on this, one cell line per individual animal was used for further analysis. Cells were cultured as normal Min6 $\beta$-cell lines in DMEM supplemented with 10\% FBS, 70 uM 2-mercaptoethanol, 2 mM L-glutamine, and penicillin-streptomycin. We selected five cell lines at passages $5-8$, obtained from five different mice from each genotype, and, in all cases, confirmed genotypes.

\section{Data access}

Microarray data for RNA expression and ChIP experiments are publicly available through ArrayExpress under accession numbers E-MTAB-1404 and E-MTAB-1402, respectively.

\section{Acknowledgments}

We thank Finn Cilius Nielsen, Rehannah Borup, and Susanne Smed (RH Microarray Center, Rigshospitalet, Copenhagen) for array hybridizations; Anouchka L. Skoudy for ES cells; Vanessa Grau for mouse colony maintenance; Carme Sanahuja for assistance; and Mark Kalisz for insightful comments. Funding is from Ministerio de Ciencia e Innovación (SAF2011-27086 to J.F., and BFU2010-18146 to M.V.), Fundación Ramón Areces (to 
M.V.), and the Biology of Liver and Pancreatic Development and Disease Marie Curie Training Program (to M.C. and J.F.).

\section{References}

Boyer LA, Plath K, Zeitlinger J, Brambrink T, Medeiros LA, Lee TI, Levine SS, Wernig M, Tajonar A, Ray MK, et al. 2006. Polycomb complexes repress developmental regulators in murine embryonic stem cells. Nature 441: 349-353.

Bracken AP, Dietrich N, Pasini D, Hansen KH, Helin K. 2006. Genome-wide mapping of Polycomb target genes unravels their roles in cell fate transitions. Genes Dev 20: 1123-1136.

Bracken AP, Kleine-Kohlbrecher D, Dietrich N, Pasini D, Gargiulo G, Beekman C, Theilgaard-Monch K, Minucci S, Porse BT, Marine JC, et al. 2007. The Polycomb group proteins bind throughout the INK4A-ARF locus and are disassociated in senescent cells. Genes Dev 21: 525-530.

Cales C, Roman-Trufero M, Pavon L, Serrano I, Melgar T, Endoh M, Perez C, Koseki H, Vidal M. 2008. Inactivation of the polycomb group protein Ring1B unveils an antiproliferative role in hematopoietic cell expansion and cooperation with tumorigenesis associated with Ink4a deletion. Mol Cell Biol 28: $1018-1028$.

Chen H, Gu X, Su IH, Bottino R, Contreras JL, Tarakhovsky A, Kim SK. 2009. Polycomb protein Ezh2 regulates pancreatic $\beta$-cell Ink4a/Arf expression and regeneration in diabetes mellitus. Genes Dev 23: 975-985.

Corkey BE, Deeney JT, Yaney GC, Tornheim K, Prentki M. 2000 . The role of long-chain fatty acyl-CoA esters in $\beta$-cell signal transduction. J Nutr 130: 299S-304S.

Delgado-Olguin P, Huang Y, Li X, Christodoulou D, Seidman CE, Seidman JG, Tarakhovsky A, Bruneau BG. 2012 Epigenetic repression of cardiac progenitor gene expression by Ezh2 is required for postnatal cardiac homeostasis. Nat Genet 44: 343-347.

del Mar Lorente M, Marcos-Gutierrez C, Perez C, Schoorlemmer J, Ramirez A, Magin T, Vidal M. 2000. Loss- and gain-offunction mutations show a polycomb group function for Ring1 A in mice. Development 127: 5093-5100.

de Napoles M, Mermoud JE, Wakao R, Tang YA, Endoh M, Appanah R, Nesterova TB, Silva J, Otte AP, Vidal M, et al. 2004. Polycomb group proteins Ring1A/B link ubiquitylation of histone $\mathrm{H} 2 \mathrm{~A}$ to heritable gene silencing and $\mathrm{X}$ inactivation. Dev Cell 7: 663-676.

Dhawan S, Tschen SI, Bhushan A. 2009. Bmi-1 regulates the Ink4a/Arf locus to control pancreatic $\beta$-cell proliferation. Genes Dev 23: 906-911.

Dhawan S, Georgia S, Tschen SI, Fan G, Bhushan A. 2011. Pancreatic $\beta$ cell identity is maintained by DNA methylation-mediated repression of Arx. Dev Cell 20: 419-429.

Eskeland R, Leeb M, Grimes GR, Kress C, Boyle S, Sproul D, Gilbert N, Fan Y, Skoultchi AI, Wutz A, et al. 2010. Ring1B compacts chromatin structure and represses gene expression independent of histone ubiquitination. Mol Cell 38: 452-464.

Ezhkova E, Pasolli HA, Parker JS, Stokes N, Su IH, Hannon G, Tarakhovsky A, Fuchs E. 2009. Ezh2 orchestrates gene expression for the stepwise differentiation of tissue-specific stem cells. Cell 136: 1122-1135.

Faust C, Lawson KA, Schork NJ, Thiel B, Magnuson T. 1998. The Polycomb-group gene eed is required for normal morphogenetic movements during gastrulation in the mouse embryo. Development 125: 4495-4506.

Garcia E, Marcos-Gutierrez C, del Mar LM, Moreno JC, Vidal M. 1999. RYBP, a new repressor protein that interacts with components of the mammalian Polycomb complex, and with the transcription factor YY1. EMBO J 18: 3404-3418.
Gu G, Dubauskaite J, Melton DA. 2002. Direct evidence for the pancreatic lineage: $\mathrm{NGN}^{+}$cells are islet progenitors and are distinct from duct progenitors. Development 129: 2447-2457.

Hager JH, Hanahan D. 1999. Tumor cells utilize multiple pathways to down-modulate apoptosis. Lessons from a mouse model of islet cell carcinogenesis. Ann N Y Acad Sci 887: 150163.

Hanahan D. 1985. Heritable formation of pancreatic $\beta$-cell tumours in transgenic mice expressing recombinant insulin/ simian virus 40 oncogenes. Nature 315: 115-122.

Hashimoto H, Vertino PM, Cheng X. 2010. Molecular coupling of DNA methylation and histone methylation. Epigenomics 2: 657-669.

Herrera PL. 2000. Adult insulin- and glucagon-producing cells differentiate from two independent cell lineages. Development 127: 2317-2322.

Hirabayashi Y, Suzki N, Tsuboi M, Endo TA, Toyoda T, Shinga J, Koseki H, Vidal M, Gotoh Y. 2009. Polycomb limits the neurogenic competence of neural precursor cells to promote astrogenic fate transition. Neuron 63: 600-613.

Huang da W, Sherman BT, Lempicki RA. 2009. Systematic and integrative analysis of large gene lists using DAVID bioinformatics resources. Nat Protoc 4: 44-57.

Jacobs JJ, Kieboom K, Marino S, DePinho RA, van Lohuizen M. 1999. The oncogene and Polycomb-group gene bmi-1 regulates cell proliferation and senescence through the ink4a locus. Nature 397: 164-168.

Ji H, Wong WH. 2005. TileMap: Create chromosomal map of tiling array hybridizations. Bioinformatics 21: 3629-3636.

Ji H, Jiang H, Ma W, Johnson DS, Myers RM, Wong WH. 2008. An integrated software system for analyzing ChIP-chip and ChIP-seq data. Nat Biotechnol 26: 1293-1300.

Juan AH, Derfoul A, Feng X, Ryall JG, Dell'Orso S, Pasut A, Zare H, Simone JM, Rudnicki MA, Sartorelli V. 2011. Polycomb EZH2 controls self-renewal and safeguards the transcriptional identity of skeletal muscle stem cells. Genes Dev 25: 789-794.

Kirkby B, Roman N, Kobe B, Kellie S, Forwood JK. 2010. Functional and structural properties of mammalian acylcoenzyme A thioesterases. Prog Lipid Res 49: 366-377.

$\mathrm{Ku} \mathrm{M}$, Koche RP, Rheinbay E, Mendenhall EM, Endoh M, Mikkelsen TS, Presser A, Nusbaum C, Xie X, Chi AS, et al. 2008. Genomewide analysis of PRC1 and PRC2 occupancy identifies two classes of bivalent domains. PLOS Genet 4: e1000242.

Lee TI, Jenner RG, Boyer LA, Guenther MG, Levine SS, Kumar RM, Chevalier B, Johnstone SE, Cole MF, Isono K, et al. 2006. Control of developmental regulators by Polycomb in human embryonic stem cells. Cell 125: 301-313.

Lewis EB. 1978. A gene complex controlling segmentation in Drosophila. Nature 276: $565-570$.

Luco RF, Maestro MA, Sadoni N, Zink D, Ferrer J. 2008. Targeted deficiency of the transcriptional activator Hnfl $\alpha$ alters subnuclear positioning of its genomic targets. PLoS Genet 4: e1000079.

Maestro MA, Boj SF, Luco RF, Pierreux CE, Cabedo J, Servitja JM, German MS, Rousseau GG, Lemaigre FP, Ferrer J. 2003. Hnf6 and Tcf2 (MODY5) are linked in a gene network operating in a precursor cell domain of the embryonic pancreas. Hum Mol Genet 12: 3307-3314.

Margueron R, Reinberg D. 2011. The Polycomb complex PRC2 and its mark in life. Nature 469: 343-349.

Mohn F, Weber M, Rebhan M, Roloff TC, Richter J, Stadler MB, Bibel M, Schubeler D. 2008. Lineage-specific polycomb targets and de novo DNA methylation define restriction and potential of neuronal progenitors. Mol Cell 30: 755-766. 
Myrsen-Axcrona U, Karlsson S, Sundler F, Ahren B. 1997. Dexamethasone induces neuropeptide Y (NPY) expression and impairs insulin release in the insulin-producing cell line RINm5F. Release of NPY and insulin through different pathways. J Biol Chem 272: 10790-10796.

O'Carroll D, Erhardt S, Pagani M, Barton SC, Surani MA, Jenuwein T. 2001. The polycomb-group gene Ezh2 is required for early mouse development. Mol Cell Biol 21: 4330-4336.

Pirity MK, Locker J, Schreiber-Agus N. 2005. Rybp/DEDAF is required for early postimplantation and for central nervous system development. Mol Cell Biol 25: 7193-7202.

Pullen TJ, Khan AM, Barton G, Butcher SA, Sun G, Rutter GA. 2010. Identification of genes selectively disallowed in the pancreatic islet. Islets 2: 89-95.

Ringrose L, Paro R. 2007. Polycomb/Trithorax response elements and epigenetic memory of cell identity. Development 134: 223-232.

Roman-Trufero M, Mendez-Gomez HR, Perez C, Hijikata A, Fujimura Y, Endo T, Koseki H, Vicario-Abejon C, Vidal M. 2009. Maintenance of undifferentiated state and self-renewal of embryonic neural stem cells by Polycomb protein Ring1B. Stem Cells 27: 1559-1570.

Schoorlemmer I, Marcos-Gutierrez C, Were F, Martinez R, Garcia E, Satijn DP, Otte AP, Vidal M. 1997. Ring1A is a transcriptional repressor that interacts with the PolycombM33 protein and is expressed at rhombomere boundaries in the mouse hindbrain. EMBO J 16: 5930-5942.

Schuettengruber B, Cavalli G. 2009. Recruitment of polycomb group complexes and their role in the dynamic regulation of cell fate choice. Development 136: 3531-3542.

Schwartz YB, Pirrotta V. 2007. Polycomb silencing mechanisms and the management of genomic programmes. Nat ReV Genet 8: 9-22.

Skoudy A, Rovira M, Savatier P, Martin F, Leon-Quinto T, Soria B, Real FX. 2004. Transforming growth factor (TGF) $\beta$, fibroblast growth factor (FGF) and retinoid signalling pathways promote pancreatic exocrine gene expression in mouse embryonic stem cells. Biochem J 379: 749-756.

Sparmann A, van Lohuizen M. 2006. Polycomb silencers control cell fate, development and cancer. Nat Rev Cancer 6: 846856.

Subramanian A, Tamayo P, Mootha VK, Mukherjee S, Ebert BL, Gillette MA, Paulovich A, Pomeroy SL, Golub TR, Lander ES, et al. 2005. Gene set enrichment analysis: A knowledgebased approach for interpreting genome-wide expression profiles. Proc Natl Acad Sci 102: 15545-15550.

Thiel G, Schuit F. 2008. No REST for healthy $\beta$ cells. Diabetologia 51: 1343-1346.

Thorrez L, Laudadio I, Van Deun K, Quintens R, Hendrickx N, Granvik M, Lemaire K, Schraenen A, Van Lommel L, Lehnert S, et al. 2011. Tissue-specific disallowance of housekeeping genes: The other face of cell differentiation. Genome Res 21: 95-105.

van Arensbergen J, Garcia-Hurtado J, Moran I, Maestro MA, Xu X, Van de Casteele M, Skoudy AL, Palassini M, Heimberg H, Ferrer J. 2010. Derepression of Polycomb targets during pancreatic organogenesis allows insulin-producing $\beta$-cells to adopt a neural gene activity program. Genome Res 20: 722-732.

Vidal M. 2009. Role of polycomb proteins Ring1A and Ring1B in the epigenetic regulation of gene expression. Int I Dev Biol 53: $355-370$.

Voncken JW, Roelen BA, Roefs M, de Vries S, Verhoeven E, Marino S, Deschamps J, van Lohuizen M. 2003. Rnf2 (Ring1b) deficiency causes gastrulation arrest and cell cycle inhibition. Proc Natl Acad Sci 100: 2468-2473.
Wang ZL, Bennet WM, Wang RM, Ghatei MA, Bloom SR. 1994. Evidence of a paracrine role of neuropeptide- $Y$ in the regulation of insulin release from pancreatic islets of normal and dexamethasone-treated rats. Endocrinology 135: 200-206.

Wang $\mathrm{H}$, Wang L, Erdjument-Bromage $\mathrm{H}$, Vidal $\mathrm{M}$, Tempst $\mathrm{P}$, Jones RS, Zhang Y. 2004. Role of histone H2A ubiquitination in Polycomb silencing. Nature 431: 873-878.

Weber M, Davies JJ, Wittig D, Oakeley EJ, Haase M, Lam WL, Schubeler D. 2005. Chromosome-wide and promoter-specific analyses identify sites of differential DNA methylation in normal and transformed human cells. Nat Genet 37: 853862.

Xu CR, Cole PA, Meyers DJ, Kormish J, Dent S, Zaret KS. 2011. Chromatin 'prepattern' and histone modifiers in a fate choice for liver and pancreas. Science 332: 963-966. 


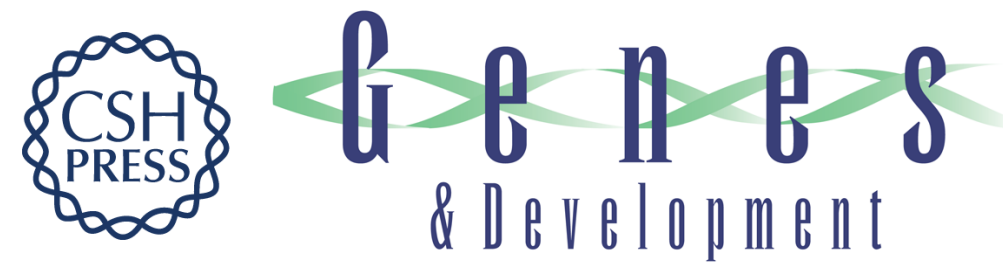

\section{Ring1b bookmarks genes in pancreatic embryonic progenitors for repression in adult $\beta$ cells}

Joris van Arensbergen, Javier García-Hurtado, Miguel Angel Maestro, et al.

Genes Dev. 2013, 27: originally published online December 27, 2012

Access the most recent version at doi:10.1101/gad.206094.112

\section{Supplemental http://genesdev.cshlp.org/content/suppl/2012/12/19/gad.206094.112.DC1 Material}

References This article cites 55 articles, 21 of which can be accessed free at: http://genesdev.cshlp.org/content/27/1/52.full.html\#ref-list-1

\section{License}

Email Alerting

Service

Receive free email alerts when new articles cite this article - sign up in the box at the top right corner of the article or click here.

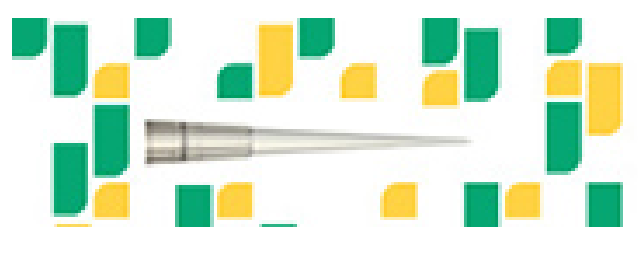

Focused on your science. 